\title{
Artigos
}

\section{A Casa do Brasil de Lisboa: uma associação de Acolhida}

\author{
Ceres Karam Brum ${ }^{1}$
}

\section{Resumo}

Este trabalho parte do estranhamento de encontrar na Europa uma pluralidade de Casas denominadas "Casa do Brasil” e que não se constituem necessariamente em lugares de habitação. Neste sentido, no presente artigo, dando continuidade às reflexões sobre as Casas do Brasil na Europa que pesquisei em Paris, Madri e Munique, abordo a experiência realizada entre 2016 e 2021, na Casa do Brasil de Lisboa (CBL). Para construir um entendimento sobre a configuração da CBL ao longo de sua existência focalizo aspectos de sua história e atuação no universo do associativismo imigrante em Portugal. A Casa do Brasil de Lisboa vem efetuando um importante trabalho de garantia dos direitos dos imigrantes, especialmente de brasileiros em Portugal. Eles a procuram com o intuito de se informar e "dialogar" com o estado português, através de um conjunto de atividades/serviços oferecidas pela Casa do Brasil de Lisboa. Com o intuito de apresentá-las desenvolvo algumas reflexões sobre o trabalho do Grupo Acolhida. Ele reúne semanalmente na Casa do Brasil de Lisboa e/ou on-line, imigrantes que desejam dialogar sobre suas experiências em Portugal. A discussão que perpassa este texto e o conecta com a Antropologia da casa, a partir do nome Casa do Brasil, destaca a casa como um lugar de simbolização coletiva e individual que extrapola sua dimensão de moradia, remetendo as noções de casa-nação, territorialização/ (des)territorialização de identidades e solidariedade imigrante na Europa. Logo, que significados adquire o nome casa nesta perspectiva? 0 que liga as Casas do Brasil na Europa e quais as particularidades da Casa do Brasil de Lisboa)? Desejo cotejar tais questões ao longo deste artigo com o intuito de analisar o trabalho desenvolvido na CBL e sua importância para a comunidade imigrante em Portugal.

\section{Palavras-chave}

Casa-nação. Etnografia. Brasilidades. Acolhida.

1 Doutora em Antropologia social, docente e pesquisadora do Departamento de Ciências Sociais da UFSM. E-mail: cereskb@terra.com.br. 


\section{Abstract}

This paper originates from the strangeness of finding in Europe a plurality of Houses named "Casas do Brasil" (Brazil Houses) that aren't necessarily constituted as housing buildings. In this sense, in this paper, I'll give continuity to the reflections regarding the Casas do Brasil in Europe I've researched in Paris, Madrid and Munich, and I address the experience carried out between 2016 and 2021 in Lisbon's Casa do Brasil (CBL). To construct an understanding regarding CBL's configuration throughout its existence, I focus on aspects of its history and operations in the universe of immigrant association in Portugal. Lisbon's Casa do Brasil has been doing and important work for guaranteeing the immigrants' rights, especially Brazilian immigrants in Portugal. They look for it with the intention to be informed and to "dialog" with the Portuguese state through a set of activities/services offered by Lisbon's Casa do Brasil. With the purpose of introducing them, I elaborate on a few reflections regarding the Acolhida Group. The group has weekly meetings in Casa do Brasil and/or online meetings for immigrants who wish to talk about their experiences in Portugal. The discussion that spans this text and connects it with the anthropology of the house, because of the name Casa do Brasil, highlights the house as a place of collective and individual symbolization that extrapolates its dimension of housing, alluding to the notions of nation-house, territorialization, (de)territorialization of identities and immigrant solidarity in Europe. Thus, what meanings does the word "house" acquire in this perspective? What connects the Casas do Brasil in Europe and which are the particularities of Lisbon's Casa do Brasil? I intend to compare these issues throughout the paper with the purpose of analyzing the work developed in CBL and its importance to the immigrant community in Portugal.

\section{Keywords}

Nation-house. Ethnography. Brazilianess. Acolhida.

\section{Palavras Iniciais}

Em março de 2016, após andar algum tempo no colorido e luminoso Bairro Alto, deparei-me com um sobrado que reconheci pela placa indicativa de Casa do Brasil de Lisboa. A casa, situada na esquina da rua Luz Soriano ${ }^{\circ} 42$, estava coberta por uma mistura de cores desbotadas e sobrepostas por tags e outras expressões pictóricas dos artistas anônimos que a tatuaram sabe-se lá quando. Soei a campainha, e a porta foi aberta por um sonido agudo que destoava do tom bucólico do cenário em que penetrava.

Segui as vozes em um hall mal iluminado e subi uma escada de madeira em "L", que me levou ao segundo andar, com duas portas comunicantes 
entreabertas, que indicavam uma sala (que intuí de espera pela disposição dos móveis). Logo em seguida, ao ser chamada, entrei em uma outra sala, com três mesas dispostas em " $u$ ", na qual trabalhavam duas pessoas. Eu me dirigi à moça a quem expliquei a que vinha. Disse-lhe que desejava pesquisar sobre a Casa. Havia enviado um e-mail naquela manhã, mas, como estava de passagem pela cidade, preferi tentar passar para conversar diretamente.

Desse primeiro contato, guardo a lembrança da simpatia ao projeto de pesquisa que apresentei ao longo do meu primeiro diálogo, em linhas gerais. Deixei uma cópia para ser submetido à diretoria da CBL e um exemplar do livro "Maison du Brésil: um território brasileiro em Paris", publicado em 2014.

Cyntia, na época, já fazia parte da diretoria da CBL que hoje preside. Ela era uma das responsáveis pelo Gabinete de Orientação e Encaminhamento e pelo Projeto Acolhida, concebido em 2013. Nesse primeiro contato, experimentei uma sensação nova de me sentir "em casa" antes mesmo de começar a pesquisa na CBL. Foi um encontro espontâneo e simpático, em que acordamos que o trabalho de campo seria desenvolvido através da minha inserção como colaboradora voluntária na associação.

No começo de julho de 2016: retornei a Lisboa com um projeto ambicioso de pesquisar "As Casas do Brasil na Europa". Iniciei, de imediato, um processo de desconstrução de uma hipótese que percebi aflorar em Portugal e em outros lugares da Europa: de que as Casas do Brasil têm um sentido ligado às questões de tradução em países em que não se fala português. Também percebi, desde os primeiros dias na CBL, uma dimensão de acolhida expressa nas falas de muitos imigrantes e em diferentes atividades que ocorriam na associação, naquele momento, e que desejo abordar ao longo deste texto.

\section{Percurso de Pesquisa}

O contato com a Casa do Brasil de Lisboa deve ser entendido dentro de um cenário mais amplo: o das Casas do Brasil na Europa. O nome Casa do Brasil tem me suscitado um estranhamento ao longo dos últimos anos. Tais casas têm um importante protagonismo na história das relações entre o Brasil e a Europa e, especialmente, dos brasileiros e não brasileiros que participam de suas atividades e/ou as habitaram nas diferentes cidades europeias em que se situam.

Porém, antes de contextualizar a Casa do Brasil de Lisboa no universo das Casas do Brasil na Europa, é necessário que me reporte à casa e aos sentidos 
que suscita bem como à Antropologia da Casa e do nome Casa do Brasil e suas potencialidades de pesquisa.

Para Brum e Russi $(2019$, p.365) a casa como substantivo remete a variadas formas de construções destinadas a habitação ou moradia temporária. De uma perspectiva etnológica são extremamente relevantes os estudos que remetem à casa em suas mais variadas dimensões arquitetônicas, estéticas e o espaço em que se constrói o quotidiano de seus habitantes como lugar de sedentarização ou de mobilidade, entre outros. Para Brum e Rosales (2018, p. 817):

Dessa forma, se pensarmos no conjunto de estudos nas Ciências Sociais que remetem à casa, não estamos diante de tema inexplorado. Nesse campo de produção, na etnologia francesa são bem conhecidos os trabalhos de Claude Lévi-Strauss (1957), ao analisar a casa Bororo em Tristes trópicos; de Marcel Griaule (1966), que estuda a casa Dogon em Dieu d'eau: entretiens avec Ogotemmêli, de Pierre Bourdieu (1980), ao interpretara Maison Kabyle em Les sens pratique e François Ruegg (2011), que estudou as habitações camponesas em La maison paysanne: histoire d'un mythe.

Em trabalhos mais recentes, as abordagens que a casa suscita se diversificam como apontam Pontes, Rossati e Jacques no artigo La maison, le chez-soi; la maison, le monde do dossiê "Habiter: maison et espace sociale" recentemente publicado:

Toute maison, à cause de ses habitants et de son contexte social et politique, fait partie d'un réseau de relations sociales mobilisant l'imaginaire, la personne, la famille, la société et l'État. La maison n'est ni seulement le produit d'individus, ni exclusivement l'espace réservé à l'intimité familiale. Toute maison, à cause de ses habitants et de son contexte sociale et politique, fait partie d'un réseau de relations sociales mobilisant l'imaginaire, la personne, la famille, la société et l'État. La maison n'est ni seulement le produit d'individus, ni exclusivement l'espace réservé à l'intimité familiale. (PONTES; ROSSATI; JACQUES: 2020, p.23)

Ao apresentarem novas possibilidades e as potencialidades de pesquisas relacionadas à casa através do conjunto de relações sociais a que a mesma suscita, os autores me permitem dialogar com a casa como lugar que extrapola uma concepção mais tradicional de habitação e lócus familiar, remetendo a imaginários do Brasil no exterior e à construção de identidades, a partir da casa. 
Neste trabalho desejo refletir a respeito da história e da "atuação" de uma associação denominada Casa do Brasil de Lisboa. Ela não se constitui habitação ou moradia, mas se liga a hospitalidade e "acolhida" de imigrantes e estudantes em Portugal, enquanto associação que se dedica ao trabalho de assessoramento de imigrantes em termos jurídicos, profissionais e psicológicos, entre outros aspectos de sua atuação, conforme irei abordar ao longo deste trabalho.

O nome Casa do Brasil remete, inicialmente, às residências estudantis que foram construídas na década de 1950-60, enquanto projetos de governo de Juscelino Kubitschek de Oliveira, com o objetivo de fomentar a formação internacional dos pesquisadores brasileiros na Europa, ao proporcionar alojamentos e outras atividades ligadas à dita "cultura" brasileira no exterior. Essas casas se constituem monumentos arquitetônicos responsáveis pela disseminação de imagens modernistas do Brasil na Europa. A Maison du Brésil de Paris e a Casa do Brasil de Madri, situadas, respectivamente, nas cidades universitárias da capital francesa e espanhola, são casas/museus para habitação temporária a estudantes de diversas partes do mundo (especialmente) brasileiros, em seus estágios acadêmicos e artísticos na Europa.

Pesquisei durante anos essas duas residências universitárias, especialmente a Maison du Brésil de Paris (BRUM: 2014), um célebre edifício de Lúcio Costa e Le Corbusier, hoje com 62 anos de existência, que tem sido um elemento importantíssimo na circulação internacional de pesquisadores na França e que foi minha casa durante os anos de 2003 e 2004, quando fiz meu estágio de doutorado em Paris.

Foi assim que nasceu o desejo de entender melhor a experiência educacional internacional que vivenciei e de tantos outros pesquisadores e seus acompanhantes que lá estiveram. Passados alguns anos, retornei à Maison du Brésil e passei a percebê-la como um lugar de memória significativa na minha história de vida e de centenas de pesquisadores brasileiros que, como eu, lá viveram para estudar em Paris ou participaram de suas atividades socioculturais. Conforme propõe Augé, ao analisar as relações pessoalmente estabelecidas com o passado através da visitação e leitura individual de um vestígio: “Ce Paris-là, ce sont mes ruines à moi, une ouvre d'art hors d'age et qui, pour cette raison, me donne le sentiment qu'elle n'existe que pour moi". (AUGÉ, 2003, p.124).

Em virtude desse processo de estranhamento, em janeiro de 2010 retornei à Europa para a realização da pesquisa. Foram 12 meses consecutivos de observação participante como residente na Maison du Brésil e um conjunto de 
trabalhos de campo e pesquisas documentais também desenvolvidos na Casa do Brasil de Madri, realizados entre junho de 2010 e fevereiro de 2013.

Desse trajeto de pesquisa, do conjunto de inquietações e resultados parciais surgiu o desejo de conceber uma reflexão que articulasse as motivações da criação desses territórios educacionais brasileiros na Europa durante o governo JK à história das residências, com as "novas" Casas do Brasil na Europa, criadas na década de 1990, que igualmente entendo como "espaços culturais nacionais brasileiros", voltados à questão da imigração.

A experiência internacional educacional de pós-graduação dos pesquisadores e dos trabalhadores imigrantes brasileiros na Europa com os quais dialoguei é perpassada por representações de ser brasileiro como pedra de toque da reconfiguração identitária no exterior. Ela mescla elementos linguísticos, espaciais, alimentares e artísticos brasileiros aos elementos locais franco-hispânico, luso-germânico. Essa articulação, conforme ensina Abelés (2008) ao analisar a globalização como um fenômeno antropológico, remete à vivência de identidades (des)territorializadas. Neste caso, de uma cultura brasileira até certo ponto inventada para ser vivida no exterior e caracterizada pela produção de estereótipos, bem como por suas desconstruções. Por sua vez, remete também à questão da história das identidades nacionais em contextos internacionalistas, conforme se configuram as cidades universitárias francesa e espanhola, caracterizados por exibições identitárias de celebração do nacional (THIESSE, 2000).

Nessas cidades universitárias, as casas nacionais apresentam características arquitetônicas que remetem ao país de origem. Para além da moradia estudantil de caráter privado em que se configuram, são espaços públicos de exibição do nacional "brasileiro", neste caso. São casas-museus inscritas no conjunto patrimonial nacional da França e da Espanha.

A par dessa dinâmica observada na Casa do Brasil de Madri e na Maison du Brésil em Paris, percebi um grande contingente de estudantes/pesquisadores e trabalhadores brasileiros em circulação internacional que participam das atividades das casas em eventos ou que acorrem a elas em busca de informações variadas. É nesse contexto de atendimento a imigrantes brasileiros no exterior que surgem as "novas" Casas do Brasil em Lisboa e Munique. Estudando essas associações, observei igualmente um conjunto de atividades que remetem à cultura brasileira no exterior. Vale destacar as festas com música e comida brasileira (feijoada, acarajé, pão de queijo, caipirinha), conferências e mesas redondas, exposições, atividades para crianças, como a "contação de histórias", que remetem à língua e às regiões brasileiras, debates, etc. 
Por remeterem ao Brasil e a suas regiões, interpreto-as como territórios brasileiros na Europa. Não se trata de territórios jurídicos, mas de lugares em que indivíduos e grupos produzem vínculos identitários desterritorializados, acionando o Brasil como referência preponderante, que articulam com a sua vida no exterior enquanto imigrantes brasileiros na Europa.

O nome "Casa do Brasil", desde a década de 1990, vem sendo utilizado para nomear associações que apoiam imigrantes brasileiros na Europa, como demonstram as Casas do Brasil de Lisboa e Munique, bem como a Casa do Brasil de Londres (concebida como associação), mas que atualmente se constitui uma empresa de prestação de serviços a imigrantes no Reino Unido. Apesar de se configurarem em projetos distintos, o nome Casa do Brasil justifica a tentativa de uma análise conjunta e de alguma forma suscita a busca dos significados a serem decifrados a partir de uma Antropologia do Nome. Para Sylvain Lazarus:

O caráter antropológico do meu propósito se define na questão do nome inominável. O nome é inominável porque é o nome de uma singularidade irredutível a outra coisa que não seja ela própria, ao passo que toda nominação abre para uma generalização, tipologia ou polissemia que manifestam a existência de uma multiplicidade heterogênea e negam a singularidade. Portanto a proposição é que o nome existe. Entenda-se a singularidade existe, mas não se pode nomeá-la, pode-se apenas captá-la pelo que, como veremos, são seus lugares. O pensamento fornece nomes que são inomináveis, mas podem ser captados por seus lugares. No termo "Antropologia do nome", o nome designa, em última análise, a vontade de captar a singularidade sem fazê-la desaparecer. (LAZARUS: 2017, p. 7):

A nominação Casa do Brasil acompanha a singularidade das relações que se processam em cada uma das 4 casas estudadas. Por certo, elas comportam similaridades (homogeneidades) que o próprio nome significa. Elas remetem ao Brasil, no exterior, e ao desejo de salientar o pertencimento a esse lugar através da vivência de aspectos que remetem a língua, música, comida, modos de ser e de viver etc. Revelam o desejo de viver a casa como nação acolhedora no exterior, em diferentes perspectivas e da criação de uma imagem para o Brasil na Europa, na década de 50/60 e nos anos de 1990, por parte do governo brasileiro (no caso das casas de estudantes) e de exercício da cidadania imigrante (no caso das associações).

A antropologia do nome nos coloca no "fio da navalha" das generalizações e singularidades, que o nome Casa do Brasil encerra. Podemos pensá-las como 
casas-nação, pois as Casas do Brasil, e como tentarei demonstrar a partir da abordagem à $\mathrm{CBL}$, carregam no próprio nome essa perspectiva/sentido de acolhida de brasileiros no exterior. Nesse sentido, o nome Casa do Brasil remete de variadas formas à nação brasileira no exterior, através de atividades que auxiliam a vida dos imigrantes brasileiros na Europa, como mediações burocráticas, profissionais, jurídicas, psicológicas e de sociabilidade oferecidas pela CBL como associação.

A ideia da casa-nação é desenvolvida por Löfgren (1999) ao estudar o sentido metafísico e existencial de cruzar as fronteiras nacionais em seus locais de entrada e saída. Ele se refere a uma pedagogia multifacetada do espaço que se expressa em relações de ansiedade e desconforto diante do desconhecido: "Another common methaphor is the nation as a house and the immigrant as a visitor knocking at the door or the window, standind at the threshold or in the back yard" (LÖFGREN, 1999, p.12). A ideia da casa-nação consiste em imaginar a nação como uma casa de portas e janelas fechadas na qual os imigrantes permanecem na soleira ou no quintal.

Embora o estado-nação os receba ou tolere de um ponto de vista legal, e as portas e janelas possam eventualmente se abrir, ao que parece a nação, corporificada na metáfora da casa construída por Löfgren, efetivamente se estrutura e dirige a seus cidadãos, com os quais celebra os mais variados vínculos de identificação e pertencimento.

A metáfora da casa como nação se materializa e complexifica no cenário da Casa do Brasil de Lisboa. Sua existência como uma associação que se configura em território do acolhimento é reveladora das dificuldades de aproximação dos imigrantes com o estado português. Um acolhimento que significa, para embasar nossa discussão, não especificamente o abrigo habitacional a que a generalidade do nome poderia nos conduzir, (quando pensamos nas casas de estudantes de Paris e Madrid, por exemplo), mas nessa abertura da casa-nação ao diálogo, à prestação de serviços aos imigrantes que a buscam. No dizer de Cyntia de Paula (Diário de Campo 1, 2019), a CBL é uma associação que atua em prol da garantia do direito dos migrantes em Portugal. Para melhor elucidar sua atuação, nessa busca pela concretização dos direitos dos imigrantes em Portugal, começarei construindo sua história através das vozes de seus fundadores e colaboradores. 


\section{Uma casa brasileira... com certeza}

A criação da Casa do Brasil de Lisboa não se resume a um episódio isolado. Os relatos de seus primeiros sócios-fundadores, que exerceram funções diretivas e de militância na associação, convergem para o reconhecimento de um conjunto de eventos que são narrados como o mito fundador da Casa do Brasil de Lisboa, conforme Brum e Vianna (2017, p.150). Podemos mesmo pensar em um processo de "construção simbólica e material da Casa", vivido ao longo de seus primeiros anos. Um período de dez anos transcorridos entre os primeiros contatos ocorridos em 1989 que levaram, posteriormente, à decisão da fundação de uma associação voltada à causa imigrante e a seu registro jurídico, como associação em Portugal.

Tal registro ocorreu em 1999, por ocasião do Decreto-Lei 115/99, que dispõe sobre o regime jurídico das associações de imigrantes e se seguiu à criação do ACIME (Alto Comissariado para a Imigração e Minorias Étnicas), instituído pelo Decreto-Lei nª $3^{\text {a }}$ 1996. A Casa do Brasil de Lisboa, como as demais associações de imigrantes, funcionou por muitos anos de maneira informal, mas extremamente atuante.

Nos parágrafos que seguem dou voz a algumas pessoas que participaram da estruturação da associação nos anos 1990. Esses protagonistas rememoraram o processo de construção da Casa do Brasil de Lisboa através de um conjunto de entrevistas e de textos. Revelam-me uma teia de significados, partilhada por seus fundadores, que se projeta como um apelo à continuidade do trabalho da Casa do Brasil de Lisboa, em prol da causa imigrante em Portugal. São igualmente produtores de vínculos identitários que passam pelo distanciamento do país e sua presença em Lisboa, em um momento de construção democrática do Brasil, dos problemas enfrentados por brasileiros em Portugal e de desejos culturais comuns partilhados em termos de música, comida, festas e, sobretudo, de mudança social.

Os fundadores da CBL se reconhecem como militantes de esquerda imbuídos da crença socialista da transformação do mundo, especialmente no caso de Alípio de Freitas, mais conhecido como Padre Alípio, que é português e esteve preso por cerca de 10 anos durante a ditadura militar no Brasil. Ele foi importante colaborador na organização das Ligas Camponesas no Nordeste brasileiro e da Ação Popular - organização da esquerda católica que ficou bastante conhecida pela atuação do sociólogo Betinho. A partir dos anos 1980, o padre Alípio, de retorno a Portugal, desenvolveu atividades como professor, jornalista e militância camponesa no Alentejo. Ele é o sócio número 1 da CBL e 
foi igualmente o primeiro editor do Jornal Sabiá, que nasceu juntamente com a Casa do Brasil de Lisboa em 1992.

Mas a CBL, apesar de sua dimensão militante, possuía também sua parcela "povão". Rosa Telles conta com alegria que a participação nas manifestações pró-impeachment de Collor de Mello foi a possibilidade de reunir pessoas e começar a festejar o Brasil em Portugal, angariar fundos para que "a associação que não vive só dos sócios" pudesse ajudar as pessoas e desenvolver seu trabalho."

A criação da Casa do Brasil de Lisboa é um episódio amplamente partilhado nas histórias de vida de seus fundadores. Possui um sentido revigorador, justificado pela necessidade de transformação da relação que o estado português vinha estabelecendo, naquele momento, com os imigrantes brasileiros. Exemplo disto é a conhecida animosidade dos dentistas portugueses ao trabalho dos seus pares brasileiros, radicados em Portugal, apesar da existência do acordo Cultural Brasil-Portugal, de 7 de setembro de 1966, que, no seu artigo XIV, regulamenta a equivalência de diplomas de profissionais brasileiros e portugueses.

Nesse episódio, a Casa do Brasil de Lisboa teve um papel político e militante fundamental, que marcou o início do seu trabalho como associação. Alípio de Freitas relata a visita que realizou com o então embaixador brasileiro José Aparecido de Oliveira ao Ministro da Saúde Português para solicitar ao governo português a legalização administrativa da prática de cirurgiões dentistas brasileiros em Portugal. Segundo ele, daí resultou a publicação da Portaria 180-A/92, de junho de 1992, que equiparava dentistas brasileiros a técnicos e permitia-lhes o exercício da profissão e, como não eram médicos dentistas, estavam vinculados ao Ministério da Saúde e não à APMD (Associação Portuguesa de Médicos e Dentistas).

A fala de Alípio é elucidativa da dimensão da atuação militante que a CBL buscou estabelecer com o estado brasileiro, presente em Portugal através de seus cônsules e embaixadores. Ao seu depoimento se soma o de Rosa Telles relatando a ajuda mútua que os encontros da Casa do Brasil de Lisboa propiciavam: "o Alípio me emprestou o dinheiro para comprar meu primeiro carro, para trabalhar como vendedora". "Eu sou a sócia n.3 da Casa, fui junto com Alípio e a Virgínia no cartório para fazer os papéis da associação."

Das entrevistas realizadas sobre a criação da Casa do Brasil de Lisboa vale destacar o caráter associativo e político conferido à CBL desde a sua criação; a abertura para um diálogo intercultural em defesa da causa imigrante alavancado pelas problemáticas suscitadas por brasileiros em Portugal; a 
recriação de uma cultura brasileira no exterior; a dimensão familiar da CBL e seu caráter de acolhimento simbolizado pelo nome Casa do Brasil.

Esses aspectos são bem salientados através da organização de atos públicos, festas, debates, textos em jornais que fundamentam as falas desses protagonistas. A dimensão de família se refere à produção de um parentesco simbólico estabelecido pela atuação na CBL entre seus membros. Uma noção de família ampliada de brasileiros em Portugal, de imigrantes que se encontram e que partilham dificuldades e afinidades, que se identificam e interagem, que fazem festa juntos de um duplo ponto de vista: para celebrar o encontro, a vida, o Brasil, o estar em Lisboa, o ser imigrante e também para que as festas possam dar continuidade ao trabalho da associação, como destacou Rosa Telles.

A CBL foi oficialmente criada em 15 de janeiro de 1992, segundo o Jornal Sabiá no 50, fev. 2002. Virgínia Paiva, sua primeira presidente, relata o episódio de seu encontro com inúmeros brasileiros em uma "boca de urna". O evento se passou nas imediações da Embaixada do Brasil em Portugal, onde ocorreu a votação. Na narrativa de Virgínia transparece a magia da crença na construção democrática do Brasil, de uma virada da esquerda, percebida por imigrantes que, como ela, estavam em Portugal:

Em 1989 o Lula foi candidato pela $1^{\text {a }}$ vez e eu muito empenhada na campanha fui fazer boca de urna na embaixada e entendi que devia tomar nota dos contatos de alguns brasileiros, dos endereços e telefones deles. $\mathrm{E}$ volto a pensar que não seria tarde nem cedo começar a pensar em uma associação, porque a história dos dentistas me desagradava imenso, a história da rejeição dos brasileiros que a princípio não percebi começou a me incomodar e comecei a ligar para as pessoas a contatar toda a gente para ver se a gente começava a marcar uma reunião, para começar a fazer qualquer coisa com relação a isto. Então a ideia da Casa do Brasil surge a partir disto e eu me sinto um bocado mãe do projeto, a maternidade da CBLé um bocado minha e eu sou muito ciumenta disto. Claro que depois quem deu à luz a CBL não fui só eu, foram outras pessoas tb. A esta altura começamos a nos reunir na casa de um casal chamado Gigi e Ló. O Carlos ainda não tinha entrado nesta história. Havia a família da Emília, o Helder Reis, o Alípio também.

Lula perdeu as eleições para Collor de Mello no segundo turno, mas a semente do encontro dos brasileiros nas imediações da embaixada frutificou o nascimento de uma associação em Portugal. Estavam lançadas as sementes da Casa do Brasil de Lisboa. Vale ressaltar que até 1996 a CBL se constitui a única 
associação voltada para brasileiros a desenvolver um trabalho de apoio aos imigrantes, atuando na supressão das lacunas deixadas pela administração portuguesa, em termos do atendimento a uma grande onda migratória, especialmente de brasileiros, recebida por Portugal a partir dos anos 1990.

O episódio da "boca de urna" é percebido por Virgínia e por Heliana Bibas e Carlos Vianna como um momento de identificação pessoal, de um dar-se conta da necessidade de fortalecer os laços entre os brasileiros que viviam em Lisboa e que partilhavam desejos e problemas comuns. Naquele momento o fato de Virgínia ter anotado em uma caderneta de endereço o nome e telefone das pessoas com quem se encontrou foi decisivo para os contatos posteriores e a criação da Casa do Brasil de Lisboa. Esses contatos se desdobraram em reuniões realizadas inicialmente nas suas casas e que, posteriormente, passaram a ocorrer na sede da Associação Cabo Verdiana. Para Virgínia:

O que pensávamos era ver o que já havia como associação e encontramos uma em Lisboa e outra no Porto. Não bastava ser um bando de brasileiros falando, mas possuirmos uma identidade jurídica. Ainda não era Casa do Brasil não era nada. Começamos a discutir estatuto, era tudo discutido muito democraticamente em conjunto. Fizemos um contato com a associação cabo-verdiana que era uma das associações mais antigas de Lisboa. Tivemos também reuniões nesta associação em que o presidente era o Arnaldo Andrade que agora é do governo cabo-verdiano e a Celeste Correia, que depois foi deputada muito interessada nas questões da imigração. Depois precisávamos de uma sede, não tínhamos dinheiro, mas conseguimos uma sala mínima sem janelas sem nada, onde ficou sendo a associação que se expandiu depois, não era a associação Abril dos militares, era a Abril da Lourdes Pintacilgo. Desta fusão, da aceitação que resultou ficou uma companheira nossa chamada Rosa Telles que depois ficou muito ativa e atuante na Casa do Brasil e continuou a caminhada conosco, isto foi em 90/91, e o embaixador do Brasil era o Lamprea.

Carlos Vianna menciona uma reunião ocorrida na Associação Cristã de Moços em que importantes decisões foram tomadas para dar início à CBL. Esse momento histórico da configuração da CBL é também lembrado e assinalado por Virgínia em sua entrevista:

Tivemos um encontro na Associação Cristã da mocidade em que Carlos Vianna participa e aí se cria a comissão instaladora da Casa do Brasil. Este é o marco histórico e a partir daí começa a discussão do nome etc. E aí já tinha mais gente, tinha o Duda Guennes um jornalista que havia chegado bem antes do que eu a Portugal, a Glaucia Nogueira, o Tadeu, a Isis, a 
Sara, a Marli que está no Brasil. O Helder Reis o José Alberto Braga, jornalista que também foi muito atuante neste início. Nesta altura começamos a nos dar a conhecer. Já tínhamos um embrião de associação, eu já tinha um cargo, estava mandatada pela associação. Visitamos todos os partidos políticos e um grande apoio que tivemos nesta altura foi do deputado do PS (que chamávamos de Nossa Senhora dos Imigrantes) e começamos a nos dar a conhecer nos jornais e começou a haver algum interesse pela associação, entrevistas no Diário de Notícias. Começamos a dizer que era uma associação de brasileiros e de amigos da Casa do Brasil, portugueses que sejam amigos dos brasileiros são muito bemvindos. Conheci através do José Alberto Braga o Agostinho da Silva e ele deu um grande apoio a nós todos e se tornou sócio honorário da Casa do Brasil. Norma Kuri correspondente do Globo, Jair Rartner da folha de São Paulo. AÍ é fundada a CBL. Eu fui a primeira presidente, e o Carlos Henrique era o vice-presidente.

Em 1992 a CBL vivenciou ativamente o impeachment de Collor. Esse não foi somente um episódio político, foi um momento de festa, do encontro de brasileiros. Uma festa de identidades, conforme relatou Poti Telles, sobre o Baile do Impeachment, que teve música e comida brasileira, no Ritz Club, decorado de verde amarelo. Nesse momento a associação já é bem conhecida e atuante. Tinha a sua sede situada na rua São Pedro de Alcântara, $n^{\circ} 63$, onde permaneceu até 2009, quando passou a desenvolver suas atividades na rua Luz Soriano, 42, também no Bairro Alto. Nesse mesmo ano também ocorreram o episódio da recusa da entrada dos imigrantes brasileiros em Lisboa e na cidade do Porto bem como medidas fundamentais para a regularização da situação dos dentistas brasileiros em Portugal.

Uma questão fundamental foi o nome escolhido para a associação. O nome Casa do Brasil vem carregado de muitos sentidos e de um peso importante. Para Carlos a escolha se liga à existência de Casas de Portugal em alguns lugares do Brasil (como Rio de Janeiro e Porto Alegre) e sua identificação com o universo imigrante português. A denominação Casa do Brasil de Lisboa seguiria o mesmo sentido das casas portuguesas, em um lugar brasileiro em Portugal.

Vale assinalar na explicação de Carlos o processo migratório como fator preponderante para a escolha do nome, que, por sua vez, justifica a existência da Casa do Brasil de Lisboa em suas dimensões materiais e simbólicas de mediação e de reciprocidade. Isto se repete nas falas a seguir, que enfatizam igualmente na CBL como espaço acolhedor e familiar de encontro entre brasileiros e portugueses. 
Para Isis e Heliana, o nome Casa está mais ligado a uma noção de acolhida, da possibilidade de encontro, ao passo que para Alípio a Casa do Brasil de Lisboa se configurou, inclusive, em um lugar tão familiar e acolhedor que, por vezes, o abrigou após uma longa jornada para passar a noite entre dois dias de trabalho intenso que o impediam de retornar à sua residência. Isis ressalta o caráter convivial e de sociabilidade da associação, nesses primeiros tempos, conforme relata:

Ainda na sede antiga, nós não íamos apenas para uma reunião, era um ponto de encontro, nem que fosse para sentar para ver a televisão e chegava alguém para conversar. Isto eu acho que se perdeu. As pessoas não vêm mais à CBL para passar um momento. Existia uma regularidade destas visitas, íamos para não fazer nada, as circunstâncias também mudaram, há sempre muito que trabalhar, pessoas para atender e não há mais fisicamente este espaço convivial da sala com uma televisão. Ela correspondia muito mais ao nome CASA neste sentido. "ERA UMA CASA BRASILEIRA COM CERTEZA". Podemos brincar com a afirmação portuguesa (uma casa portuguesa com certeza)! Porque estava sempre aberta, pela informalidade, porque sabíamos que íamos sempre encontrar algum brasileiro conhecido, havia um pouquinho pelo menos esta maneira de estar brasileira em que eu não tenho que marcar duas semanas antes para me encontrar, diferente da maneira de funcionar portuguesa (não é boa nem má). A CBL era esse chopinho informal e havia uma parte de seus associados que incentivavam e alimentavam este espírito. Havia pessoas-chave, havia o Duda Guennes, que era um desses homens que falam de tudo, entendem de tudo, ele vivia sozinho em Portugal e estava sempre por lá. A casa íamos até lá em busca do aconchego em um país estrangeiro, mesmo que isso não fosse muito consciente. Era um espaço onde nos reconhecíamos. O governo Cavaco de direita fazia com que nos aproximássemos, isto nos fornecia um elemento de união, de identificação, mesmo que estivéssemos legalizados havia uma solidariedade entre os imigrantes.

Segundo Heliana, "as pessoas passavam sempre no final do dia para conversar um pouco, para resolver os problemas, dividir as tarefas e organizar as atividades". Para ela a CBL sofreu transformações significativas ao longo de sua história, pois a princípio era mais ativa à noite. Com o passar do tempo as atividades de atendimento da Casa do Brasil de Lisboa exigiram um outro tipo de estrutura (mais diurna) e a diversificação de suas atividades.

A fala de Heliana nos leva a um outro aspecto muito importante de sua história: a espontaneidade da participação e do voluntariado na resolução de 
questões voltadas à questão imigrante. Um compromisso de engajamento para a transformação da situação da dura realidade desse grupo em Portugal, mas que a princípio não envolvia a profissionalização. Tratava-se de uma tarefa militante de múltiplas dimensões. Essa espontaneidade também se percebe na frase de Rosa:

Ninguém me pediu nada, mas eu fui fazendo, organizando as festas, indo atrás dos músicos. Assistia suas apresentações e se gostava os convidava para virem tocar na CBL nas nossas festas de sextas-feiras. Vendia os bilhetes antes pra evitar prejuízo. Se ainda não havia público, pedia para começarem a tocar e aí a sala enchia de gente! A festa estava formada.

Isis, ao mencionar sua chegada a Portugal em 1993, relata sua atuação no Jornal Sabiá:

- Vá a CBL eles têm muitas atividades e eu vim. Eu perguntei como poderia ajudar e me propus a organizar as matérias de jornais que a casa possuía. A casa tinha uma outra natureza, era um pessoal menos jovem, com experiência política no Brasil, o Carlos e a Heliana, o Alípio de Freitas e a Virgínia. O Sabiá aconteceu desde o início, era feito com muita dificuldade, funcionou, depois tivemos que reduzir a periodicidade, as pessoas não tinham tempo e também dinheiro. O Jornal vai de 1992 e 2002 e depois deixa de ter periodicidade regular. O financiamento era embutido no custo dos projetos da casa, tentávamos fazer um pouco de publicidade, mas era residual. Todo o trabalho era voluntário, fazíamos isto num final de semana (paginação), o custo se resumia a gráfica. Mesmo nos períodos de crise sempre tentamos manter o jornal, porque entendíamos que era um ponto importante de comunicação da casa.

Os relatos desses momentos demonstram a presença dos fundadores em várias atividades: como as feijoadas preparadas no Club Ritz narradas por Eliana e a presença de Alípio, Rosa e seu marido Poti no aeroporto de Lisboa para auxiliar no diálogo com as autoridades de imigração que barravam a entrada de imigrantes brasileiros. Poti relata que muitas vezes não conheciam essas pessoas, mas se responsabilizavam para que pudessem entrar e começar uma nova vida em Portugal.

A antropóloga Bela Feldman-Bianco menciona a atuação central da Casa do Brasil de Lisboa no texto "Entre a "fortaleza" da Europa e os laços afetivos da "irmandade" luso-brasileira: um drama familiar em um só ato". O texto se desenvolve a partir da análise de um episódio polêmico que envolveu BrasilPortugal, em 1993, um grupo de brasileiros, impedidos de entrar em Portugal, 
provenientes da cidade de Governador Valadares, que ficaram retidos no aeroporto de Lisboa em condições desumanas. $\mathrm{O}$ episódio desencadeou uma grave crise diplomática entre Brasil e Portugal e na qual a CBL, como associação, atuante em prol da defesa dos direitos dos imigrantes, teve um importante protagonismo.

Através de uma análise dos discursos dos atores envolvidos, publicados na imprensa brasileira e portuguesa, quais sejam: os estados portugueses e brasileiros, a Casa do Brasil de Lisboa como uma das associações de apoio aos imigrantes brasileiros em Portugal e os brasileiros e brasileiras barrados no aeroporto Portela em Lisboa, Feldman-Bianco (2001) efetua uma interpretação desse conflito diplomático. Constrói uma etnografia dessa cena polêmica, que abrange a legislação portuguesa e suas repercussões, diante das associações em Portugal, até o final da década de 1990.

Para a autora, a reconfiguração dos cenários de imigração transnacional produziu transformações nas relações entre as antigas metrópoles e colônias. O Brasil, que até 1960 recebeu forte imigração portuguesa, passa a se configurar país de emigração. Com um perfil extremamente qualificado, profissionais brasileiros começam a perceber Portugal como um espaço de referência e saída para a crise a partir dos anos 1980.

Exemplo disto são também os textos publicados na imprensa por Carlos Vianna como um porta-voz da CBL, em repúdio à manifestação do embaixador português no Brasil sobre os brasileiros barrados em Lisboa e no Porto, bem como os eventos "Um abraço no Brasil", organizado em torno da Chancelaria brasileira nas Laranjeiras com a presença de muitos brasileiros, seguido por um grande espetáculo ocorrido no teatro Mario Mattos, que reuniu músicos e artistas brasileiros narrados por Heliana, e que foi promovido pela CBL "Lusofonia em concerto: aquele abraço irmão" .

Esse conjunto de atividades conferiram visibilidade à Casa do Brasil de Lisboa e sua identificação com a causa da imigração, especialmente de brasileiros, em Portugal. Plantaram sólidas raízes para sua continuidade e superação dos desafios vividos cotidianamente pela associação. Eles também projetaram o Brasil e as suas coisas em Lisboa, pois, como destaca Heliana: "Naquele período não havia o que temos hoje em termos de comida e bebida brasileira em Lisboa. A caipirinha Casa do Brasil era famosíssima!"

Entre as atividades festivas que remetiam ao Brasil, divulgando comida, bebidas e música brasileira e a atuação em prol da garantia e concretização dos direitos dos imigrantes em Portugal, a CBL foi adquirindo visibilidade como associação. Foi se afirmando como um território brasileiro em Lisboa, através 
da simbolização do Brasil para além dos estereótipos culinários e musicais ao atuar, igualmente, como ator político de suma importância.

Gustavo Behr relata o aconchego da casa que tinha festas memoráveis, porque "apesar das salas não serem muito grande era um espaço que podia ser ocupado, dava para dançar onde quisesse, mesmo nas salas dos computadores." (...) "Meus amigos adoravam, a gente podia fazer barulho como quisesse, os vizinhos não nos importunavam." Rosa Telles lembra: "E quando lá pelas duas as festas acabavam nos arranjávamos para continuarmos à noite em uma discoteca ali perto. Tempo bom!"

É neste sentido que a Casa do Brasil de Lisboa pode ser entendida como uma casa-nação. De várias formas ela comunica o desejo de acolhimento para brasileiros em Portugal, um lugar de sociabilidade e de vivência da língua e de múltiplas expressões da brasilidade, promovendo, desde a sua fundação, a inserção dos imigrantes brasileiros, intermediando seu diálogo com o estado português. Quer através da prestação de serviços para a regularização de sua situação, quer através de atividades de inserção profissional, apoio jurídico e de formação que vem desenvolvendo, entre outros aspectos, como destaca Isis Alves:

O CDOC existia informalmente com os poucos recursos que tínhamos na CBL. Com as doações de pessoas e com o apoio da embaixada nos anos 90 se consolidou. Foi no período Itamar e ele esteve na inauguração do CDOC em 1996. Isto nos deu condições de organizar as coisas, adquirir livros, comprar pastas, estantes, termos um arquivo organizado. Tivemos um estagiário que ajudou a fazer isto, houve um trabalho profissional neste sentido compramos um software para organizar os arquivos. Eu diria que este trabalho foi recompensado porque havia uma procura, nós tínhamos uma demanda de estudantes secundários, de pesquisadores sobre imigração e todos passaram pelo CDOC. Ainda nos anos 90 tivemos um congresso sobre imigração em 1997 que deu visibilidade à casa, vieram pesquisadores de vários países e do Brasil, e este foi um momento muito importante. A biblioteca foi junto com o CDOC. Havia o material de jornais e revistas. Como não havia nenhum centro que se dedicasse à imigração brasileira, todo mundo vinha à CBL, e isso fazia um pouco a diferença, estudantes que vinham fazer pesquisas sobre o Brasil. Houve um momento que havia um movimento intenso de pesquisa e depois o dos secundaristas deixou de existir e demandas pontuais de pesquisadores brasileiros. Um outro momento é a pesquisa sobre a segunda vaga de imigração e depois pessoas que buscaram no CDOC coisas que não estavam na internet, depois cessou. Quando há alguém venho e mostro a documentação. 
A ideia da CBL como casa-nação brasileira em Portugal se percebe igualmente nas falas de Carlos e Heliana sobre sua participação na boca de urna para Lula, que assinalo como o mito de origem da casa e que é vivenciado em cada um dos relatos dos fundadores: o desejo de criar uma associação para fortalecer politicamente os brasileiros que viviam em Portugal. A sutileza da questão está no reconhecimento da necessidade da existência de uma associação militante politicamente, mas apartidária, conforme destacam TODOS os relatos. Uma casa-nação acolhedora da diversidade de opiniões e da pluralidade de seus atores. Mas, ao contrário do que possa aparentar, todos os envolvidos, apesar de ampla experiência em militância política, não possuíam grande experiência com questões relacionadas com imigração - afora o fato de serem imigrantes brasileiros em Portugal. Portugueses de retorno à Portugal, no caso de Alípio de Freitas, que viveu um longo período no Brasil, retornando ao país sem documentação.

A experiência de deslocamento para Portugal é a geradora da identificação com a causa, norteadora da construção da casa. O espírito associativo decorre das biografias de cada um. O encontro de 1989 promove a explosão da brasilidade militante, o exercício do dever cidadão em Portugal e o desejo de festejá-lo através da casa. Carlos Vianna no livro "A derrota: reflexões desordenadas sobre uma geração", sintetiza essa dimensão e nos brinda com o seu entendimento sobre esse período inicial da CBL ou de como a casa se configurou no Brasil militante reinventado em Lisboa, que continua a fazer sentido, a preencher a vida de seus fundadores e a atrair inúmeros colaboradores, conforme relata Carlos Vianna:

Construímos com muitos companheiros e com muita alegria e entusiasmo um pouquinho do Brasil em Portugal. Assim a militância continuou, cívica, associativa, na luta pelos direitos dos e(i)migrantes, uma luta política e social central hoje no mundo. E esta construção, esta militância nos fez criar mais laços com Portugal, novas responsabilidades, novos protagonismos. A Casa do Brasil passou a ser uma mediação permanente com a militância do passado, com o Brasil, com o povão migrante, com a cultura, as festas. Dizia um amigo sócio e diretor da casa que tínhamos que ir às festas de sextas-feiras para tomar a nossa dose na veia de Brasil e aguentar a semana toda. Passados 24 anos, de muitas conquistas por sinal, continuamos ligados à Casa do Brasil, ainda que com menos intensidade. Eu e a Heliana fazemos parte da atual $13^{a}$ diretoria da casa, eleita em julho de 2015, agora em cargos discretos e com atuação mais apagada. Como de quase todas as diretorias anteriores. (VIANNA: 2016, p.169-170). 
A CBL continua viva na memória de seus fundadores. Ela se confunde com a história de vida dessas pessoas. Foi o sonho de transformação social que se tornou realidade e por quem dedicaram ou continuam a dedicar boa parte de suas vidas. Por isto faz sentido falar em mito fundador da CBL, pela mudança estrutural que provocou na vida dessas pessoas e que justifica esse recontar. A boca de urna pela virada democrática de 89 e sua consolidação em 1992, com o impeachment de Collor de Mello, produziram mais do que um eco, alicerçaram uma casa-nação brasileira "com certeza" na terra lusitana!

Os elementos destacados nas falas dos fundadores demonstram a CBL como uma associação política que se caracteriza como espaço de mediação para a concretização dos direitos imigrantes em Portugal. Pelas dificuldades narradas nessas falas, fica claro que, apesar de se tratar de uma "mesma" língua, os brasileiros em Portugal encontram inúmeras dificuldades burocráticas, jurídicas e psicológicas. É nesse sentido que é possível pensar a CBL como uma casa-nação que auxilia a relação dos imigrantes com a complexidade do estado português, conforme abordarei a seguir.

\section{A Casa do Brasil de Lisboa: uma associação de acolhida}

Passados 27 anos de sua criação, a CBL, para além do lugar de memória e da importância na história de vida de seus fundadores, continua viva e atuante no cenário associativo português. A continuidade de sua existência vem contando com a atuação sucessiva de um conjunto de pessoas que lá trabalham como voluntários e como técnicos financiados por diferentes projetos, bem como com a mensalidade paga pelos sócios

A CBL que conheci em 2016 passava por um momento de crise sem precedentes no cenário associativo português, ainda decorrente dos anos críticos vivenciados por Portugal entre 2011 e 2014. A situação era tão dura que mesmo o pagamento do aluguel da casa à Câmara de Lisboa e as faturas de eletricidade exigiam uma ginástica de Rita Alho (tesoureira) a qual todos nós que vivíamos o cotidiano da CBL partilhávamos. A Casa viveu nos anos de 2016 e 2017 o fantasma de fechar as portas e encerrar as atividades sucessivas vezes.

Fui me inteirando dessa situação de forma abrupta desde o momento em que comecei o trabalho de campo, ao mesmo tempo que vivenciei o despertar para a dimensão de Acolhida que quero destacar neste texto. Para tanto, é importante pensar no circuito de atuação da CBL, no cenário da imigração neste momento, situando - segundo Agier (2018), que discute a situação da 
hospitalidade aos estrangeiros na contemporaneidade - a importância das dimensões que as associações adquirem no trabalho pelos imigrantes em cenários nacionais adversos:

En Alemagne, en Italie ou en Espagne, les États, les régions et les provinces ainsi que la Communauté européenne soutiennent um certain nombre d'initiatives municipales ou des réseaux associatifs locaux. Dans ce cas-lá, une rélation s'installe avec le monde associatif et local, comme pour encarner le début d'une politique de logement adoptant um príncipe d'hospitalité comme préatable. Mais, en admettant qu'um jour les solutions existeront les unes à côté des autres, ce ne sont encore que les prémices de l'histoire d'um monde mobile. (AGIER, 2018, p. 87).

A reflexão de Agier é válida igualmente para Portugal, em termos de financiamento, guardadas as particularidades do seu cenário associativo e particularmente da CBL, que percebi ao longo do trabalho de campo.

A aprendizagem da nação portuguesa, pelos brasileiros que migram para Portugal por motivos plurais, se processa desde a preparação da viagem, da busca de um visto de trabalho, de estudo ou mesmo da sua saída como turista e da decisão de ficar na Europa sem que a documentação tenha sido solicitada anteriormente a sua saída do Brasil. A CBL se constitui um território "brasileiro" parte desse cenário. Seus agentes e colaboradores efetuam uma pedagogização da nação portuguesa (de difícil decodificação, conforme percebi na fala de algumas pessoas) ao auxiliarem, indicando alguns caminhos através de informações e serviços, conforme apresenta Barreto (2011, p. 311) no artigo Entre a política e a cultura: associativismo imigrante em Portugal, em que analisa o papel da Casa do Brasil de Lisboa no cenário de imigração em Portugal:

A associação conta com uma programação diversificada, com atividades que vão desde os grupos de trabalho, biblioteca e centro de documentação, apresentação de filmes e documentários, até atendimentos mais específicos, aulas de dança e dias de música (convívio às sextas-feiras) e banco de dados para empregos (rede UNIVA, gerenciada pelo ACIDI).

Neste sentido, a Casa do Brasil de Lisboa possibilita e/ou intermedia um possível aprendizado para a integração (ao menos de um ponto de vista da necessária legalização, da obtenção dos documentos para poder permanecer) em Portugal, mas igualmente a possibilidade de encontrar trabalho como processo de auto e exo-reconhecimento do imigrante pelo estado que o abriga. 
Ela também se configura em espaço de sociabilidade, de encontro, universo educacional e de vivência das brasilidades em Lisboa, como as demais Casas do Brasil aqui apresentadas.

\section{0 espaço Casa do Brasil de Lisboa e suas atividades}

No início de julho de 2016, para iniciar o trabalho de campo, toquei a campainha e, como de praxe a porta, se abriu e reencontrei o escuro hall de entrada que se comunica ao primeiro piso através de uma longa escada de madeira. É nesse andar que se situam os gabinetes (GIP, GOE e GAJ - Gabinete de Atendimento Jurídico) e uma grande sala de espera com vários símbolos brasileiros distribuídos nas paredes, com a bandeira nacional, próxima a uma das grandes janelas.

Menos perceptível para quem chega ao térreo, à direita da escada, está o acesso aos banheiros e a um grande salão em verde e amarelo, território do bar, onde ocorrem as festas e as promoções, bem como rodas de conversas e palestras. Há uma porta que se abre para o exterior, convidando a quem passa nessa esquina, nos dias de acarajé e outras festas, a entrar. O cheiro de comida e a música que se ouve remetem ao Brasil, produzem um trabalho de memória sensorial acionado pelo cheiro de dendê misturado aos sons de bossa nova, lembranças do Brasil e da Bahia, que invade a tradicional Lisboa do Bairro Alto. Uma mistura instigante e calorosa!

Na época, a CBL tinha parcerias com o Acarajé da Carol que acontecia em algumas quintas-feiras do mês e com a Sra. Tapioca, no sábado. Durante o verão, os turistas e alguns habitués passavam no fim da tarde pra beber um copo e degustar a comida brasileira que estava à venda. Mas, apesar da memória brasileira acionada, o cheiro de dendê era algo que nos incomodava a todas no primeiro andar, onde trabalhávamos nos gabinetes. 


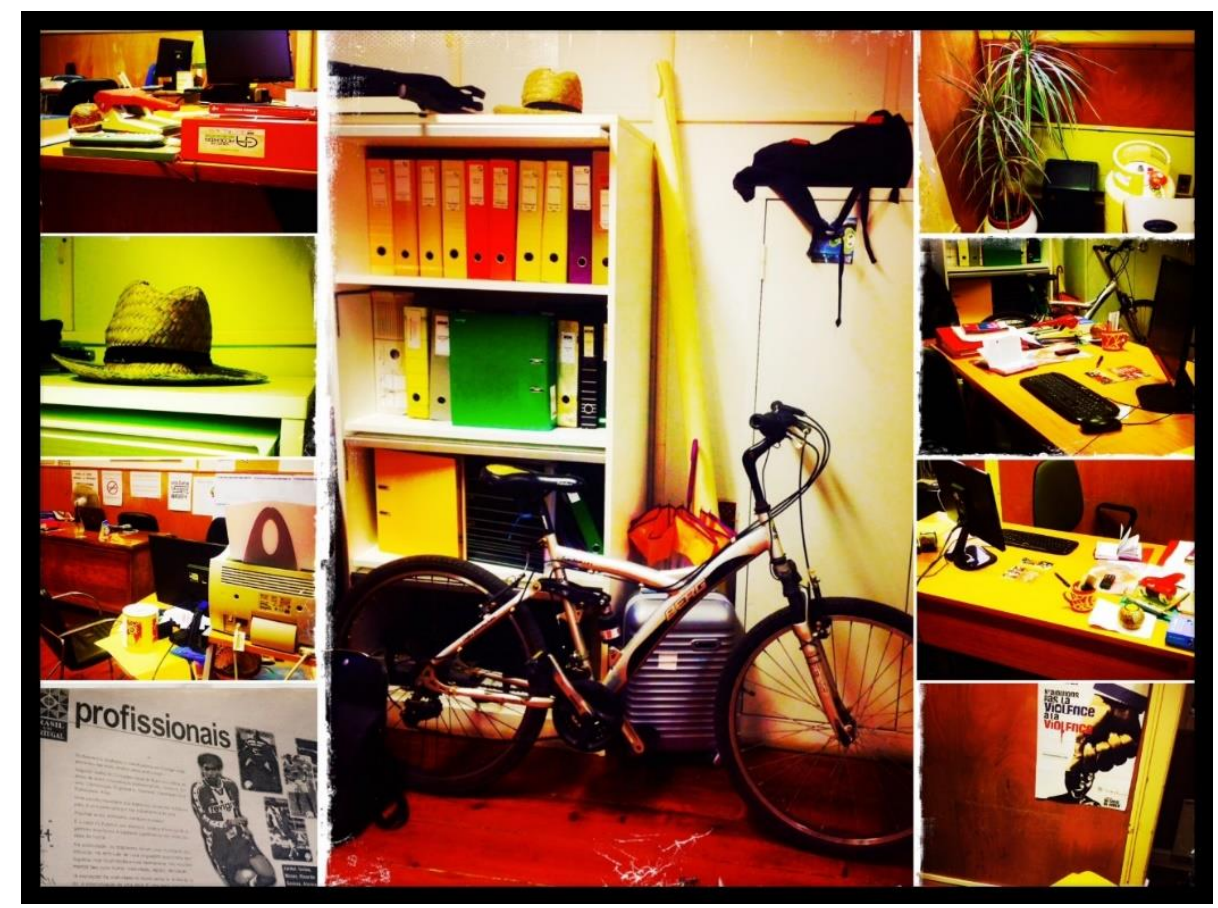

Casa do Brasil de Lisboa. Acervo exposição “As Casas do Brasil na Europa.”

Foto Alain Demarcy: 2017.

O segundo andar da casa é todo ocupado pelo salão onde ocorrem as aulas de ioga, dança, teatro etc. e que se transforma em dias de conferências e mesas redondas em território de ricos debates e de tomadas de decisões e de diálogo nas sessões do Grupo Acolhida. As paredes que dão acesso ao terceiro piso onde se localiza a biblioteca e o CDOC (Centro de Documentação da CBL) são decoradas com os tambores de maracatu que revelam cenas coloridas de um Brasil plural e com fotos de visitantes ilustres recebidos na CBL e dos seus colaboradores.

O espaço da casa foi se revelando abrupta e surpreendente para mim. Iniciei meu aprendizado de campo pesquisando as últimas edições do Jornal Sabiá (publicação que a CBL possuía desde a sua criação e que foi publicada até 2017), para me familiarizar com o vocabulário da associação e seus atores. Nos dias subsequentes tive acesso ao CDOC e continuei a pesquisa documental, dividindo-me entre o trabalho de secretaria e a consulta dos arquivos. 


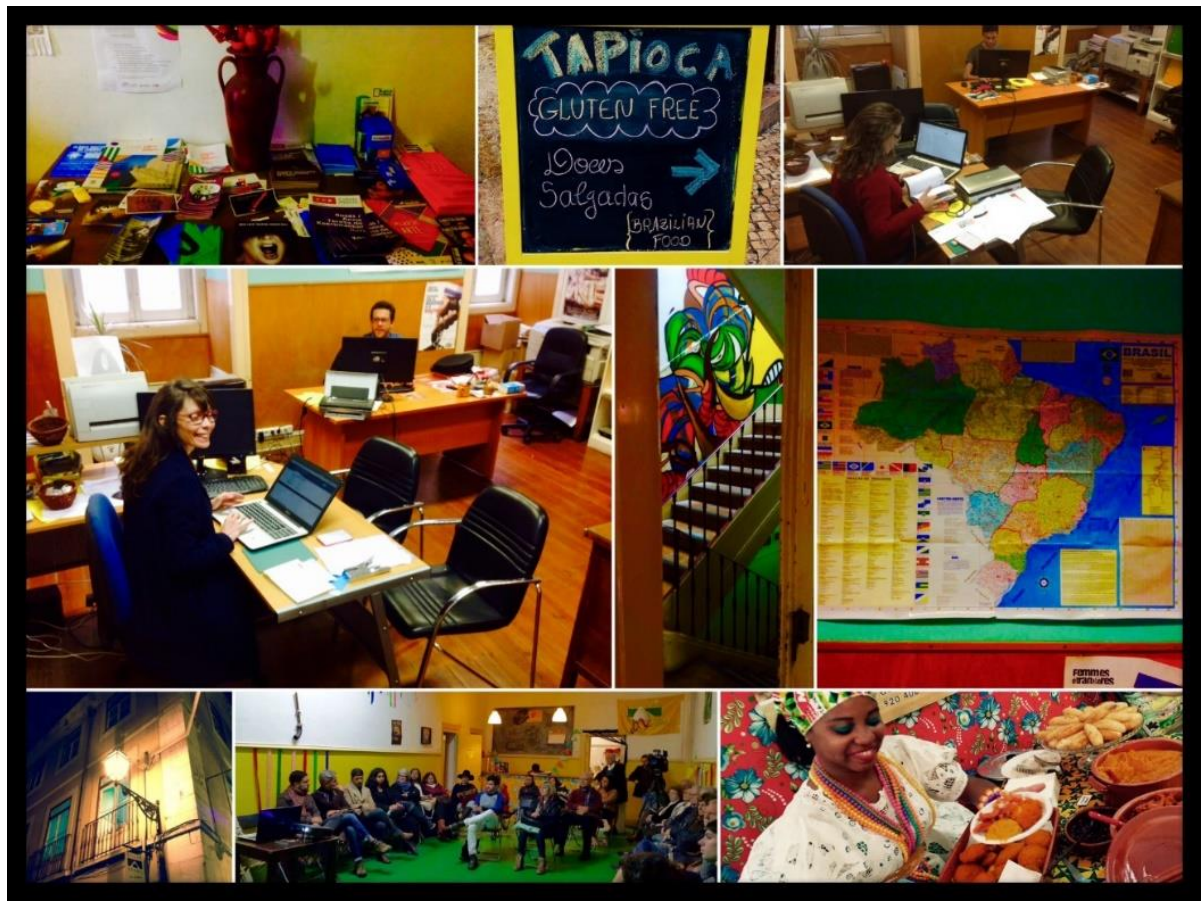

Casa do Brasil de Lisboa. Acervo exposição “As Casas do Brasil na Europa."

Foto Alain Demarcy: 2017.

Meu processo de aprendizagem na CBL, como as demais pessoas com quem conversei, se deu de forma situada, conforme me relataram Janine, Patrícia e Andressa - técnicas contratadas para prestação de serviço pela CBL. Aprendese fazendo, errando e perguntando como se faz aos que lá estão naquele dia. Trata-se de um processo de educação da atenção, como descreve Ingold (2018). É o trabalho voluntário que propicia o aprendizado, na CBL. É ele que leva a consulta à legislação e ao conhecimento da burocracia portuguesa com quem se tem que dialogar, entre outros processos formativos.

As tarefas diárias de atender ao telefone, abrir a porta, receber as pessoas que vinham atestar sua situação de desempregados junto ao GIP ou inscrever seus currículos no banco de dados, organizar a agenda de atendimento dos gabinetes, dialogar com os colaboradores e visitantes/frequentadores, foram me propiciando uma experiência de Antropologia como educação, conforme propõe Ingold (2018), que redundou no conhecimento da CBL como pesquisadora. E, especialmente, no aprendizado do trabalho voluntário e engajamento às questões de imigração, nos diálogos com Rita e Cyntia para a preparação de projetos para captação de fundos para a casa, em cada passo da 
organização do livro (comemorativo dos 25 anos da CBL) e na participação do Jornal Sabiá e nas discussões para resolver problemas imediatos que se apresentam diariamente.

A concepção de antropologia como educação de Ingold entende a antropologia como um processo de imersão em um grupo, participando de sua vida e, de alguma forma, aprendendo a ser um deles, para além de um estudo sobre uma determinada realidade/grupo pesquisado. Uma visão de antropologia que pressupõe o "com", em que a situação de trabalho de campo cria laços profundos ao longo do tempo partilhado e incide em dimensões éticas, das quais destaco o comprometimento com a continuidade da existência da CBL.

No processo de construção da pesquisa das Casas do Brasil na Europa, no tocante especialmente à Casa do Brasil de Lisboa, minha relação com o campo pode ser descrita como uma relação de aprendizado e de transformação. É nesse sentido que se inscreve, como desejo salientar, a reciprocidade entre a minha atuação como pesquisadora e a Casa do Brasil de Lisboa. Creio que aqui, vale acrescentar, à percepção de uma Antropologia com de Ingold, a visão de uma antropologia do "como", enquanto possibilidade de "preservação/proteção" e continuidade da cultura em estudo, por reconhecer sua importância, como destaquei.

Em 2016 eu dividia com Rita e Cyntia a sala do GOE, onde atendia ao telefone, organizava a agenda e encaminhava as pessoas que chegavam para atendimento. Algumas vezes a sala também abrigava outros trabalhadores voluntários que apareciam alguns dias da semana. Chegava por volta das 14 horas, fazia um trabalho de secretária, sem nenhuma experiência, e tive muita dificuldade de entender o português de Portugal ao telefone. Passei a fazer parte de um universo de pesquisa em que o engajamento é implícito como possibilidade de aceitação pelo grupo e explícito como retorno em termos da atuação em diversas atividades que envolvem a casa e seus colabores.

Meu retorno a CBL em dezembro de 2018 e 20219 para dar continuidade à colaboração iniciada em 2016 se inscreve nessa perspectiva, com o objetivo de produzir uma antropologia multivocal, do qual este texto é a primeira experimentação. Fui acolhida com a abertura de sempre. Percebi mudanças substanciais no funcionamento da CBL, decorrentes de uma nova gestão em diálogo com o cenário de financiamento europeu ao associativismo português.

O Gabinete de Inserção Profissional, que em 2016 tinha como uma das tarefas receber imigrantes em situação de desemprego, para atestar sua existência junto ao CNAI, está atualmente mais voltado à atuação junto a 
diversas etapas da construção de um banco de dados que disponibiliza currículos para ofertas de emprego em Portugal, orientando todas as etapas do processo. Recebemos diariamente (na secretaria) vários interessados e os encaminhamos ao GIP. As pessoas expressam seu desejo de encontrar um trabalho, a esperança de uma nova inserção e o significado desse serviço oferecido pela CBL sem custos aos imigrantes. Muitas vezes me contaram suas histórias de recém-chegados ou retornados à Lisboa e seu desejo de uma vida melhor em Portugal. O GIP através da atuação de Patrícia Benderode promove processos seletivos para empresas, como a recente seleção efetuada pelo supermercado Pingo Doce para diversos cargos na empresa que, pela primeira vez, admitiu contratar imigrantes ainda em situação de regularização.

Com o agendamento de uma hora, as técnicas do GOE Janine Martins e Andressa Moraes recebem entre 11 e 18 horas, diariamente, imigrantes, em sua maioria brasileiros. É um trabalho de esclarecimento, de intermediação do diálogo entre os imigrantes e o estado português, com o objetivo, no dizer de Andressa, de "promover a autonomia das pessoas", a partir de informação qualificada e confiável sobre a burocracia portuguesa com a qual se convive nos processos de regularização. Para Janine, a experiência de imigração é "intensa" como "nascer de novo", pois se deve fazer tudo o que se demorou toda uma vida no Brasil, num curto espaço de tempo, com o objetivo de se regularizar em Portugal e recomeçar uma nova vida por aqui.

Alguns casos específicos, que envolvem questões jurídicas, são encaminhados ao GAJ (Gabinete de Aconselhamento Jurídico). Esse é um serviço destinado aos sócios da casa. Parte igualmente importante é o desenvolvimento do projeto Tertúlia, que ocorre quinzenalmente, às quintasfeiras à noite na CBL. São rodas de conversas sobre assuntos relacionados à imigração, tais como a Lei de Nacionalidade portuguesa, a integração em Portugal de estudantes migrantes às universidades, a imigração e a população LGBT. O projeto Tertúlia, coordenado por Cyntia de Paula, conta com a participação de duas técnicas (Janine e Patrícia). Os convidados introduzem a temática da noite, dando início ao debate com os presentes. Tertúlia tem um papel propositivo que vai além das trocas de experiência entre os presentes. Um de seus objetivos é influenciar a própria transformação da realidade portuguesa e seus mecanismos de exclusão, buscando a garantia dos direitos dos imigrantes através, por exemplo, da sugestão de aspectos a serem transformados na legislação e da produção de informações corretas ao público presente. 
As atividades que se desenvolvem na CBL são militantes no sentido associativo do termo. O conjunto de serviços e o universo de diálogo apresentados delineiam seus contornos atuais e as perspectivas futuras de um trabalho voluntário que é, ao mesmo tempo, produtor e produto de identificação entre aqueles que o desenvolvem na associação. Talvez ele seja uma das chaves para compreendermos a longevidade da Casa no cenário associativo português. É preciso pensar no pertencimento ao universo imigrante protagonizado por grande parte dos trabalhadores voluntários e chamar a atenção para uma situação de circulação de imigrantes na CBL que caracteriza sua atuação, história e clientela. No entanto, essa não é a única chave explicativa para sua dinâmica.

Traçar um perfil dos colaboradores que desenvolvem as atividades na CBL não é tarefa fácil, em virtude do risco e restrições que as generalizações contemplam. Igualmente não é fácil caracterizar o universo extremamente vasto das pessoas que a procuram em busca de seus serviços e atividades. Para caracterizar os colaboradores valho-me de minha experiência como trabalhadora voluntária para a realização da pesquisa entre 2016 e 2020.

A maioria são jovens colaboradoras na faixa dos 25 aos 45 anos, com formação superior e que compatibilizam sua atuação militante na CBL com cursos de pós-graduação em Lisboa, Porto e Coimbra na área de sua atuação. O público que acorre a CBL em busca de seus serviços são imigrantes trabalhadores e trabalhadoras de variadas idades e com situação econômica relativamente precária. São predominantemente jovens. A análise dos registros dos sócios da CBL é reveladora de uma realidade mais plural em termos etários, de gênero e situação econômica, o que também se confirma nas ditas atividades culturais - debates, festas e no Grupo Acolhida, que abordarei a seguir.

\section{0 grupo Acolhida}

Uma forma de também entendermos a CBL como casa-associação é o Grupo Acolhida. As suas atividades se realizam semanalmente. São reuniões para troca de experiência mediadas por uma das colaboradoras da casa. O grupo inspira um sentido de hospitalidade a que se liga a ideia de uma casa, simbolizada e materializada nos diálogos que o constituem. Para Agier (2018, p.29) a hospitalidade, vista de uma perspectiva antropológica, extrapola a dimensão ética abordada pela filosofia. Ela se cinge à vida real, não possui uma dimensão prescritiva, deve partir do campo e possui dimensões políticas: 
Dans ces pratiques locales - domestiques, associatives, communales, etc - l'hospitalité est une sommes des gestes que finissent par déranger la politique qui opere, elle, dans um territoire et um imaginaire toujours nationaux. Mais quelle est cette politique de - ou dans - l'hospitalité? C'est d'abbord celle qui nait de la rélation à trois qui j' ai evoque plus haut, la décision d'accuellir um migrant procédant d'um désaccord qui je ressens à l'égard de l'hostilité affiché par mon État ou de son refus d'agir. Le geste se politize d'autant plus que l'État s'y oppose ou le condanne. Dans ce processus de politisation, l'insatisfaction à l'égard du gouvernement signifie qu'on en attend encore quelque chose (AGIER, 2018, p.140).

O projeto Acolhida pode ser entendido através dessa percepção política de hospitalidade. Ele foi criado em 2013 e desde então ocorre semanalmente na CBL às quartas-feiras à tarde, recebendo uma pluralidade de pessoas para encontrarem apoio, um porto seguro para partilharem suas experiências em Portugal, suas alegrias e dissabores, para realizarem um diálogo franco e honesto sem temer a irregularidade e a liminaridade da situação que caracteriza a maior parte de seus participantes imigrantes.

Participei do Acolhida entre 2016 e 2017 e voltei a acompanhar suas atividades entre dezembro de 2018 e fevereiro de 2019. A frequência no grupo às reuniões que acontecem nas quartas-feiras entre 16 e 17h30, em diferentes espaços da CBL, é variável. Quando percebemos que as pessoas começam a chegar, escolhemos um dos espaços desocupados da casa (o menos barulhento e mais confortável, conforme época do ano de frio ou calor intenso - porque não temos na CBL climatização), arrumamos as cadeiras em roda e começamos a sessão, que é entrecortada pela campainha que toca, anunciando a chegada de novos participantes.

O início da sessão é pontuado pela apresentação dos objetivos da realização do grupo Acolhida (propiciar a troca de experiências de imigração e o enriquecimento pessoal e do grupo com a partilha de informações e sentimentos), de sua história e solicitação de preenchimento de lista de presenças que serve para os relatórios do projeto e sua comprovação de financiamento. No momento seguinte acontece a apresentação de cada um dos presentes dizendo de onde vem, quanto tempo está em Portugal e em que atua. É bem frequente, já na apresentação, aparecerem dúvidas sobre a situação de regularização em Portugal como motivação para a participação no grupo, bem como desabafos e relatos pessoais que justificam o comparecimento na sessão, conferindo uma tonalidade ao diálogo que irá pesar, de alguma forma, na escolha do tema da sessão apresentado logo a seguir pela coordenadora. A 
partir desse momento, as falas se tornam mais espontâneas, não há uma ordem previamente estabelecida, nem tempo de fala, apenas a mediação, quando necessária, da coordenação, como nos casos de utilização do espaço do grupo para consultas muito pessoalizadas (quando é sugerido um agendamento em um dos gabinetes da CBL ou encaminhamento a outra associação/informação de um serviço especializado que possa auxiliar ou informar).

Ao longo das sessões do Acolhida participei de discussões sobre os temas identidade, integração, sonhos, expectativas, pertencimento, medo, entre outros, e, inclusive, tive a oportunidade de coordenar uma das sessões (por conta de uma dor de dente da Janine - atual mediadora do grupo, em fevereiro) em que escolhi "contato" como tema para debatermos.

A realização do Grupo Acolhida ao longo de seus quase 8 anos de existência é uma das chaves de compreensão da $\mathrm{CBL}$, de sua dimensão casa como representação da hospitalidade. O Acolhida, ao se configurar em um espaço semanal aberto ao diálogo e troca de experiência do universo imigrante, inspira um conjunto de interpretações que nos autoriza a caracterizar a CBL como um lugar de apoio, receptivo, que acolhe, em suma, que, como casa, está de portas abertas a receber e dialogar com quem vem participar do grupo com suas inquietações, incertezas e medos. Podemos entender o Grupo Acolhida, no contexto da Casa do Brasil de Lisboa, como uma territorialização da hospitalidade:

L'hospitalité acquiert um sens politique diferent lorsqu'elle engage le choix d'um autre mode de vie moin urbain, moins individualisé, moins dépendant des cadres institués. C'est le signe d'une politique imediate,soucieuse d'instaurer pour soi-même d'autres régles de solidarité et de féderer autor d'elles une "communauté" (réseau, village, quatier), à rebours des príncipes défendues par des gouvernements lointains, hostiles, courbés sur la défense de la nation, de l'identité, du territoire. (AGIER, 2018, p.140).

Vale aproximar a proposta de Agier em termos de uma hospitalidade política que se processa e inspira as reuniões do Grupo Acolhida à metáfora da casa como nação de Löfgren (2009), referida em momentos anteriores deste texto. Em um país que não é o nosso, a existência de uma Casa do Brasil com serviços especializados para garantir os direitos imigrantes em Portugal significa a possibilidade de ultrapassarmos a soleira e o quintal do mundo português para COMEÇARMOS a adentrar, como brasileiros, a partir dessa 
"acolhida" da CBL, em suas múltiplas atividades e especialmente através do cenário do Grupo Acolhida, em Portugal.

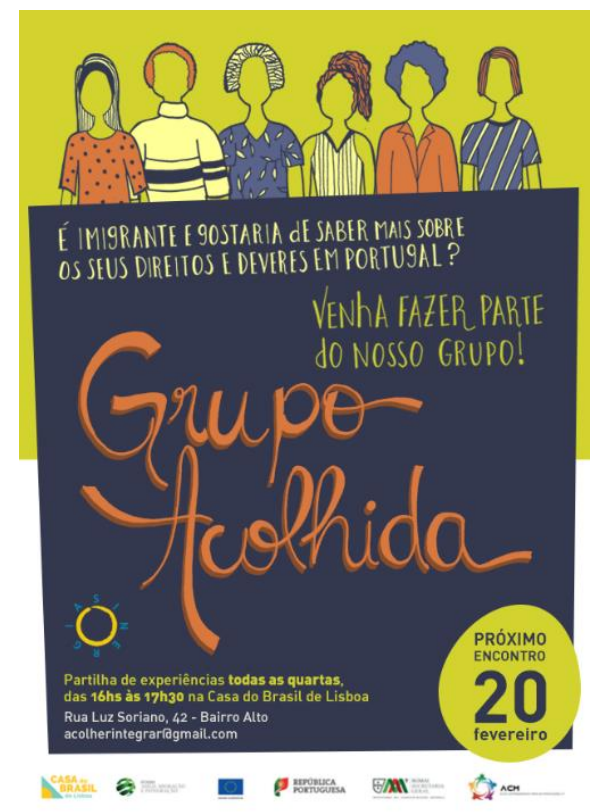

Apesar de momentos duros e áridos partilhados através dos relatos de discriminação, racismo, xenofobia, falta de educação, dentre outros vivenciados nas sessões do Grupo Acolhida, com relação à hostilidade enfrentada pelos brasileiros em Portugal, nossa opinião é de que saímos sempre mais leves do que chegamos, encontramos pessoas com quem nos identificamos e que nos fortalecem com a troca de experiências, além de percebermos que há uma equipe de pessoas com quem podemos contar na CBL. Construirmos a partir da participação na Casa um universo de sociabilidade, um pedacinho do Brasil no exterior, como tantas vezes nos confidenciaram.

\section{Palavras Finais}

Para Rosales e Brum (2018, p.817) a casa na contemporaneidade adquire novos papéis que ultrapassam o universo privado dos indivíduos em cenários nacionais e internacionais de deslocamento. Ela se reinventa! Isto ocorre, sobretudo, no atual cenário pandêmico que se protrai desde março de 2020, 
como destacam Pontes, Rossati e Jacques (2020, p.1). Inegavelmente estamos diante de reinvenções da casa:

(...) La pandémie nous a fait vivre de façon inédite dans nos sociétés contemporaines, $c^{\prime}$ est que la maison, bien plus qu'un refuge, qu'un lieu de réconfort et un espace de préservation de l'intimité, est un espace poreux, un microcosme du monde social, un espace physique et symbolique où les différents marqueurs sociaux - genre, génération, race et classe sociale - trouvent leur place. (PONTES, ROSSATI, JACQUES: 2020, p.1).

Neste trabalho tentei apresentar a CBL através de sua história e atividades como uma casa-nação que se constitui território brasileiro na Europa. Ela apresenta dimensões de solidariedade e hospitalidade em virtude de suas propostas de atuação ensejadas nas atividades que desenvolve. No contexto pandêmico, a CBL também se modificou, como demonstra a fala de Patrícia Benderode:

Desde que começou a pandemia, não paramos de funcionar. Estamos agora em teletrabalho disponibilizando os serviços do GOE e do GIP (os dois com atendimentos via telefone e e-mail). O Grupo Acolhida está agora online, via zoom todas as quartas-feiras. No dia 26 de fevereiro lançamos em parceria com a Câmara de Lisboa o Portal Lisboa Acolhe. Em janeiro começamos a desenvolver o projeto Migrante Participa em Sintra. Também há mais dois projetos muito interessantes em atividade: o Migramyths e o Migrar com Direitos, mas não sei bem em que pé estão. Cíntia pode explicar melhor esses dois. (Patrícia Benderode. Mensagem recebida em 8 de março de 2021 via messenger)

A CBL se reinventa como casa para continuar se consolidando como associação. Desejo concluir este texto assinalando a complementaridade da importância da continuidade de seu trabalho que, mesmo em um cenário sanitário, tem se mantido.

Destaco também o interesse que tem suscitado em inúmeros pesquisadores, ao longo de sua história. Os motivos que os trazem à CBL são plurais. Passam, no mais das vezes, pela busca do entendimento de questões referentes à imigração em Portugal (FELDMAN-BIANCO, 2001) e da atuação do associativismo (BARRETO, 2011) em razão das dimensões históricas, sociológicas e antropológicas que suscitam, por exemplo. Esse interesse tem sido tão intenso que atualmente um grupo de colaboradores da CBL está 
construindo uma proposta de criação de um Grupo de Pesquisa para "evitar que sejamos sempre fonte de pesquisa, sem um retorno pra gente que trabalha pela casa no dia a dia" (Diário de campo, 2019-1).

Por isto entendo a divulgação e discussão dos resultados desta pesquisa para além de uma formalidade, mas como parte importante desse processo de discussão e negociação para a continuidade da existência da CBL e de suas relações com o "mundo acadêmico" brasileiro e português. A CBL se reinventa. Invertem-se e se mesclam os papéis da casa e dos pesquisadores que ela acolhe, onde é preciso, para entender o universo do associativismo, vivê-lo em sua plenitude a partir de CBL. Habitar a casa... para além de visitá-la, pois, como nos mostra a poesia de Sophia de Mello Andresen: "Há na casa algo de rude e elementar, que nenhuma riqueza mundana pode corromper e, apesar do seu lado de solidão e do seu isolamento na duna, a casa não é margem, mas antes convergência, encontro, centro." (ANDRESEN, 2013, p.52). Traços de acolhida e hospitalidade que a Casa do Brasil imprime através de suas atividades e afetividades.

\section{Referências}

ABÉLÉS, Marc. (2008). Anthropologie de la globalisation. Paris: Payot \& Rivages.

AGIER, Michel. (2018). L'étranger qui vient: repenser l'hospitalité. Paris: Seuil.

ANDRESEN, Sophia de Mello Breyner. (2013). Histórias de terra e mar. Porto editora.

AUGÉ, Marc. (2003). Le temps en ruines. Paris: Galilée.

BARRET0, Alessandra Siqueira. (2011). Entre política e cultura: associativismo imigrante em Portugal in MALAUD, Andrés; FLÓREZ, Fernando C. (org.) Migração, coesão social e governação. Lisboa ICS, 2011, p. 301322.

BRUM, Ceres Karam. (2009) Maison du Brésil: a brazilian territory in Paris. Vibrant, p. 91-122. Disponível em: http://www.vibrant.org.br/downloads/v6n1_br um.pdf

BRUM, Ceres Karam.

(2014). Maison du Brésil: um território brasileiro em Paris. Porto Alegre: Evangraf.

BRUM, Ceres Karam; VIANNA, Carlos.

(2017). Casa do Brasil de Lisboa: um projeto vitorioso. Lisboa. MX3 Artes Gráficas.

BRUM, Ceres Karam; ROSALES, M. V. (Eds.)

(2018). Dossiê A Casa: deslocamentos, temporalidades e habitabilidades Século XXI: Revista de Ciências Sociais, v.8, Ed. Esp., p. 817822.

BRUM, Ceres Karam; RUSSI, Adriana. (2019). Sob diferentes tetos: etnografando casas e revelando dimensões educativas e patrimoniais. Etnográfica. vol. 23, n. 3. 2019, p.693-715.

FELDMAN-BIANCO, Bela.

(2001). Entre a "fortaleza" da Europa e os laços afetivos da "irmandade" luso brasileira: um drama 
familiar de um só ato in CASTRO, Mary Garcia (org.) Migrações internacionais: contribuições para políticas. Brasília: PNPD, p.151-176.

INGOLD, Tim.

(2018) L'anhropologie comme éducation. Rennes: Presses Universitaires de Rennes.

LAVE, Jean.

(1996). Teaching as learning in practice. Mind, culture and activity, v. 3, n. 3, p. 149-165.

LAZARUS, Sylvain.

(2017) Antropologia do nome. São Paulo:

UNESP, 2017.

LÖFGREN, Orvar.

(1999). "Crossing borders. The nationalization of Anxiety. Ethnologia Scandinavica. vol. 29, p.527.

PONTES, Heloisa; ROSSATII, Camila; JACQUES.

(2020). La maison, le chez-soi; la maison, le monde in Dossie Habiter: Maison et space sociale. Brésils: sciences humaines et sociales. 18, https://journals.openedition.org/bresils/index.

html
THIESSE, Anne-Marie.

(2000). A criação das identidades nacionais. Lisboa: Temas e Debates.

VIANNA, Carlos.

(2016). A derrota: reflexões desordenadas de uma geração. Lisboa: MX3 Artes Gráficas.

\section{Recebido em}

setembro de 2020

\section{Aprovado em}

março de 2021 